\title{
Growth and nutrient accumulation of Anacardium othonianum Rizz. seedlings grown in nutrient solution
}

\author{
Layara Alexandre Bessa ${ }^{1 *}$, Fabiano Guimarães Silva ${ }^{1}$, Marialva Alvarenga Moreira ${ }^{1}$, \\ João Paulo Ribeiro Teodoro ${ }^{1}$, and Frederico Antônio Loureiro Soares ${ }^{1}$
}

\begin{abstract}
Knowledge about the growth and nutritional aspects of Anacardium othonianum Rizz. ('caju-de-árvore-do-cerrado'), which is a native fruit of the Brazilian Cerrado (savannah), is still incipient. The objectives of the present study were to characterize growth and nutrient accumulation of $A$. othonianum seedlings grown in a nutrient solution. The experiment was designed in randomized complete blocks with four replicates and six treatments, and the experimental period was $180 \mathrm{~d}$ after transplanting (DAT). Each treatment corresponded to an evaluation period that was performed every $30 \mathrm{~d}$. During each sampling period, characteristics related to growth and nutrient accumulation in the plant were evaluated. Plant growth was continuous throughout the cycle with the following maximum values at 180 DAT: $16.76 \mathrm{~cm}$ for stem length, $8.09 \mathrm{~mm}$ for stem, 11.27 leaves per plant for the number of leaves, and $329.60 \mathrm{~cm}^{2}$ for leaf area. The monthly rates of plant fresh matter and DM accumulation were 3.15 and $1.05 \mathrm{~g}$, respectively. The accumulation of nutrients in A. othonianum seedlings had the following order: $\mathrm{Ca}>\mathrm{N}>\mathrm{K}>\mathrm{P}>\mathrm{Mg}>\mathrm{S}$ for macronutrients and $\mathrm{Fe}>\mathrm{Mn}>\mathrm{B}>\mathrm{Zn}>\mathrm{Cu}$ for micronutrients.
\end{abstract}

Key words: Biomass production, Brazilian savannah, hydroponic cultivation, macronutrients, micronutrient.

\section{INTRODUCTION}

Anacardium othonianum Rizz. belongs to the Anacardiaceae family. It is a native fruit plant of the Brazilian Cerrado (savannah), which is commonly known as 'caju-de-árvore-do-cerrado' (tree cashew of the cerrado), 'cajuzinho', and 'cajuí'. It is a tree species with an approximate crown height and diameter of 3 to $4 \mathrm{~m}$ and it stand outs from the other species in the Central Region of Brazil because it is the most economically important native cashew species (Agostini-Costa et al., 2006). The mature fruit coloration varies from yellow to red, and the yellowish-white pulp is consumed fresh or as juices, liqueurs, candies, and alcohol infusions. The roasted nut (true fruit) is consumed with salt, and it has high oil content (Correa et al., 2008).

The commercial exploration of cashew trees is closely linked to the production of seedlings, and the first step is to obtain healthy seedlings that can be established in nurseries, which will ensure the health of the plant in the field (Barros, 2002). The quality of the seedlings is a fundamental factor for achieving homogeneity, rapid development, and early production, thereby ensuring the expansion of this crop in Brazil. To obtain high quality

${ }^{1}$ Instituto Federal Goiano, Campus Rio Verde, Caixa Postal 66, CEP: 75901-970 Rio Verde, Goiás, Brasil.

"Corresponding author (layara.bessa@ifgoiano.edu.br).

Received: 6 January 2013.

Accepted: 11 June 2013.

doi:10.4067/S0718-58392013000300014 seedlings, it is necessary to meet the appropriate nutrient demand. Therefore, the formation of seedlings constitutes a crucial stage in the production process and may allow farmers to obtain better quality plants in nurseries to withstand the adverse conditions of the field. Notable increases in the growth and quality of seedlings may be achieved through mineral fertilization, which helps with better development, early development, and greater survival in the field.

Growth analysis is used to interpret the plant's shape and utility (Hunt et al., 2002). The principles and practices of the analysis have the objective of describing and interpreting the performance of a particular species growing under natural or controlled environmental conditions. The accumulation of DM throughout the plant cycle is the essence of growth analysis, and it is complemented by quantification of the leaf area. The leaf area over time is important for the interception of photosynthetically active radiation. The determining factor of DM accumulation is photosynthetic efficiency, which may vary according to the cultivar, soil conditions, climate conditions, and crop management.

The indices involved in the growth analysis indicate the capacity of the assimilatory system of the plants in synthesizing (source) and allocating organic matter in various organs (sinks) that depend on photosynthesis, respiration, and translocation of photoassimilates of the $\mathrm{C}$ fixation sites to the utilization or storage locations where organ growth and differentiation occur. Therefore, growth analysis expresses the morphophysiological conditions 
of the plant and quantifies net production derived from the photosynthetic process, which is the result of the performance of the assimilatory system during a certain period of time. The kinetics of growth allow the plant's growth pattern to be understood mathematically with the possibility of quantifying differences among plants species, and production systems (Taiz and Zeiger, 2004).

Growth can be characterized at specific points in certain periods of the plant cycle. The growth and development of plants, especially of DM weight and the successive development stages, have been studied to rationalize cultivation methods. In the absence of a growth curve, DM weight production is important given that it provides a good approximation of nutrient accumulation (Sousa and Coelho, 2001).

Plant DM weight is used to indicate growth intensity, which provides information on crop DM accumulation patterns, thereby allowing for a better understanding of the factors related to mineral nutrition and, consequently, to fertilization given that the absorption of nutrients is influenced by the plant growth rate (Marschner, 1995). The rate of nutrient absorption is an important reference to provide these nutrients in amounts appropriate for proper plant development during the various stages of plant development (Gurgel et al., 2010), which may aid in the management of fertilization while the seedlings remain in the nursery.

Thus, the objective of the present study was to characterize growth and nutrient accumulation of $A$. othonianum seedlings grown in a nutrient solution.

\section{MATERIALS AND METHODS}

The experiment was conducted in a greenhouse at the plant tissue cultivation laboratory of the Federal Institute of Goiás, Rio Verde Campus (1748'15.9' S, 5054'19.5' W) during from January to September 2011.

Anacardium othonianum fruits were collected at the Gameleira farm located in the municipality of Montes Claros, Goiás (1606'20” S, 51¹7'11” W; 592 m a.s.1.) The voucher specimen of the plant material was deposited at the Jataiense Herbarium of the Universidade Federal de Goiás (UFG), Jataí Campus, under collection number 3793. Seeds were manually extracted, washed with running water, and then subjected to an application of carboxin (5,6-dihydro-2-methyl-1,4-oxathiine-3-carboxanilide) + thiram (tetramethylthiuram disulfide) fungicide $200+$ $200 \mathrm{~g} \mathrm{~L}^{-1}$ (Vitavax-Thiram 200 SC, Chemtura Industria Quimica do Brasil, Rio Claro, Brazil) at $300 \mathrm{~mL} 100 \mathrm{~kg}^{-1}$ seeds.

The sowing was performed in plastic trays $(50 \times 35 \times$ $8 \mathrm{~cm}$ ) containing sand as a substrate. At $30 \mathrm{~d}$ after sowing, when three or four completely developed leaves were present, seedlings were transferred to $8 \mathrm{~L}$ pots containing a Hoagland and Arnon (1950) nutrient solution at 50\% ionic strength for a period of $30 \mathrm{~d}$.
During the experiment, plants were grown under an average irradiation of $200 \mu \mathrm{mol} \mathrm{m} \mathrm{m}^{-2} \mathrm{~s}^{-1}$, and the nutrient solution was maintained under constant aeration with compressed air. The $\mathrm{pH}$ was adjusted daily to $5.5 \pm 0.5$ with the addition of $\mathrm{HCl}$ or $\mathrm{NaOH}$ when necessary, and the nutrient solution was changed with the criterion of $30 \%$ depletion of the initial value of electrical conductivity.

The experiment consisted of six treatments arranged in randomized blocks with four replicates. Each treatment was one sampling period in $30 \mathrm{~d}$ intervals beginning on the date of seedling transplantation. Each experimental plot consisted of an $8 \mathrm{~L}$ pot of nutrient solution containing two plants.

In each evaluation period $(30,60,90,120,150$, and $180 \mathrm{~d}$ after transplantation; DAT), plants were collected, and growth was determined by means of the following characteristics: stem length (SL), stem diameter (SD), number of leaves (NL), and length of the longest root. Leaves, stem, and roots were then separated, and leaf area (LA) was evaluated. The LA was obtained from the integration of the images of the leaves into image treatment software SigmaScan Pro 5 (Systat Software Inc. SSI, San Jose, California, USA). The sampled parts were weighed to obtain fresh weight, and then dried in a forced air oven at $65{ }^{\circ} \mathrm{C}$ until reaching a constant dry weight. After drying, leaves were ground in a Wiley style mill equipped with a 20 mesh sieve, and ground leaves were then taken to the leaf analysis laboratory of the Universidade Federal de Lavras (UFLA) to determine amounts of nutrients (N, P, K, Ca, Mg, S, Fe, Cu, Zn, B, and $\mathrm{Mn}$ ) following the method proposed by Malavolta et al. (1997). Using the values for DM weights and amounts of each nutrient in leaves, nutrient contents in plants were calculated by multiplying dry weight of leaves, stems, and roots by the concentration of each nutrient to obtain nutrient contents in $\mathrm{g} \mathrm{plant}^{-1}$.

Data underwent ANOVA and regression analysis using Sisvar and Table curve 2D software (Jandel Scientific, 1991). The regression models were selected by using the largest coefficients of determination and determining the significance of the regression coefficients with a t-test at a $5 \%$ probability level.

\section{RESULTS AND DISCUSSION}

\section{Growth characteristics}

Throughout the production cycle of the A. othonianum seedlings during the six evaluation periods, there was a continuous increase in plant growth as evaluated by SL, SD, NL, LA, fresh matter (FM) weight, and DM weight (Figures 1 and 2). The root length was not influenced by the evaluation periods with an average value of $15.47 \mathrm{~cm}$.

The estimated NL and LA per plant increased to 11.27 leaves and $329.60 \mathrm{~cm}^{2}$ at 180 DAT, respectively. The plants displayed a continuous increase in the LA index indicating that the constant emergence of new leaves 

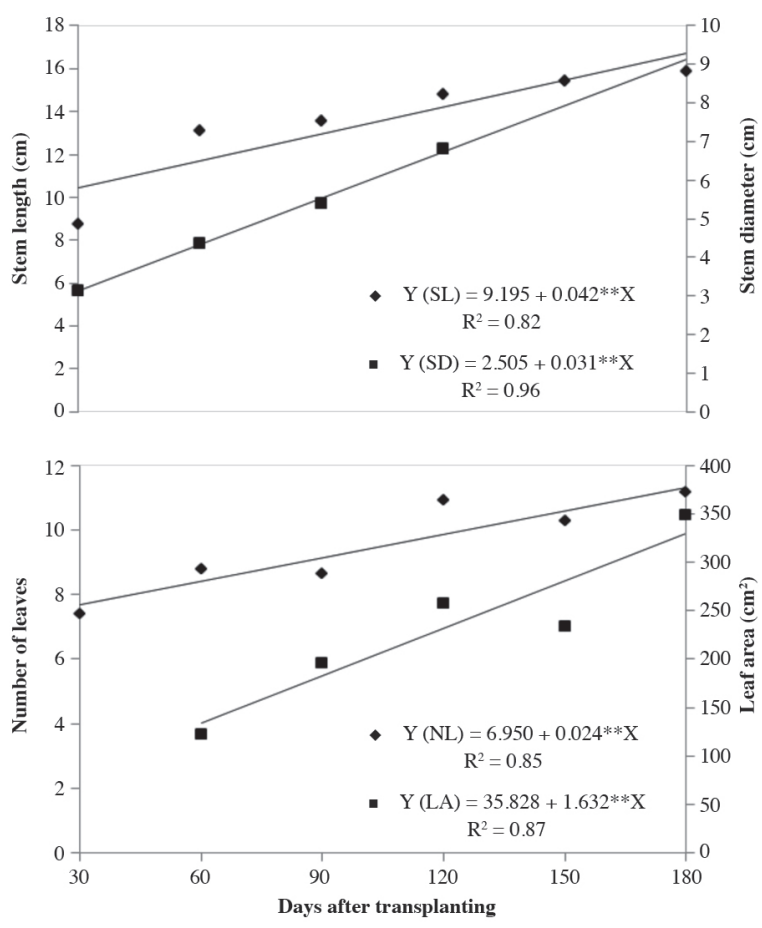

**Significant according to a t-test $(\mathrm{p}<0.01)$.

Figure 1. Stem length (SL), stem diameter (SD), number of leaves (NL), and leaf area (LA) of Anacardium othonianum seedlings as a function of days after transplanting.

or their expansion was greater than the processes of senescence and abscission.

The initial growth was slow, with a small increase in the monthly growth rate of $1.26 \mathrm{~cm}$ for SL, 0.93 for $\mathrm{SD}, 0.72$ leaves per plant for $\mathrm{NL}$, and $48.96 \mathrm{~cm}^{2}$ for LA
(Figure 1). In soursop (Annona muricata L.) seedlings, Barbosa et al. (2003) observed an average fortnightly growth of $3.3 \mathrm{~cm}$ in height and $0.51 \mathrm{~mm}$ in stem diameter. The estimated daily increase was $0.042 \mathrm{~cm}$ for SL, 0.031 $\mathrm{mm}$ for SD, 0.024 leaves per plant for $\mathrm{NL}$, and $1.623 \mathrm{~cm}^{2}$ for LA, corresponding to increases of 12.05, 27.07, 9.39, and $57.74 \%$ for every $30 \mathrm{~d}$ of evaluation for SL, SD, NL, and LA, respectively (Figure 1).

Similarly, the accumulation of FM and DM weights increased as a function of the evaluation period (Figure 2). At 180 DAT, weights of total FM, leaf FM, stem FM, and root FM reached the largest estimated values, with values of $21.92,4.61,6.16$, and $11.16\left(\mathrm{~g} \mathrm{plant}^{-1}\right)$, respectively (Figure 2). The estimated monthly accumulated FM weights were $3.15 \mathrm{~g}$ for total FM weight, $0.42 \mathrm{~g}$ for leaf FM weight, $0.96 \mathrm{~g}$ for stem FM weight, $1.74 \mathrm{~g}$ for root FM weight, which corresponded to $1.70,0.56,2.36$, and $2.36 \%$ for the monthly increase in weights of total FM, leaf FM, stem FM, and root FM, respectively.

According to the regression equations, the accumulation of weights of total DM and leaf matter reached 6.64 and $1.82 \mathrm{~g} \mathrm{plant}^{-1}$, respectively, at $180 \mathrm{DAT}$ (Figure 2). In addition to the leaves, stem and root DM weights contributed to the total accumulation reaching 1.95 and $2.91 \mathrm{~g} \mathrm{plant}^{-1}$, respectively. Throughout the periods evaluated in this experiment, roots were the main sinks of the plant.

The estimated monthly accumulated DM weights were $1.05 \mathrm{~g}$ for total DM weight, $0.18 \mathrm{~g}$ for leaf DM weight, $0.33 \mathrm{~g}$ for stem DM, and $0.54 \mathrm{~g}$ for weight of root DM. These accumulations represented a daily increase of $0.035,0.006,0.011$, and $0.018 \mathrm{~g}$ for weights of total DM, leaf DM, stem DM, and root DM, respectively. Barbosa

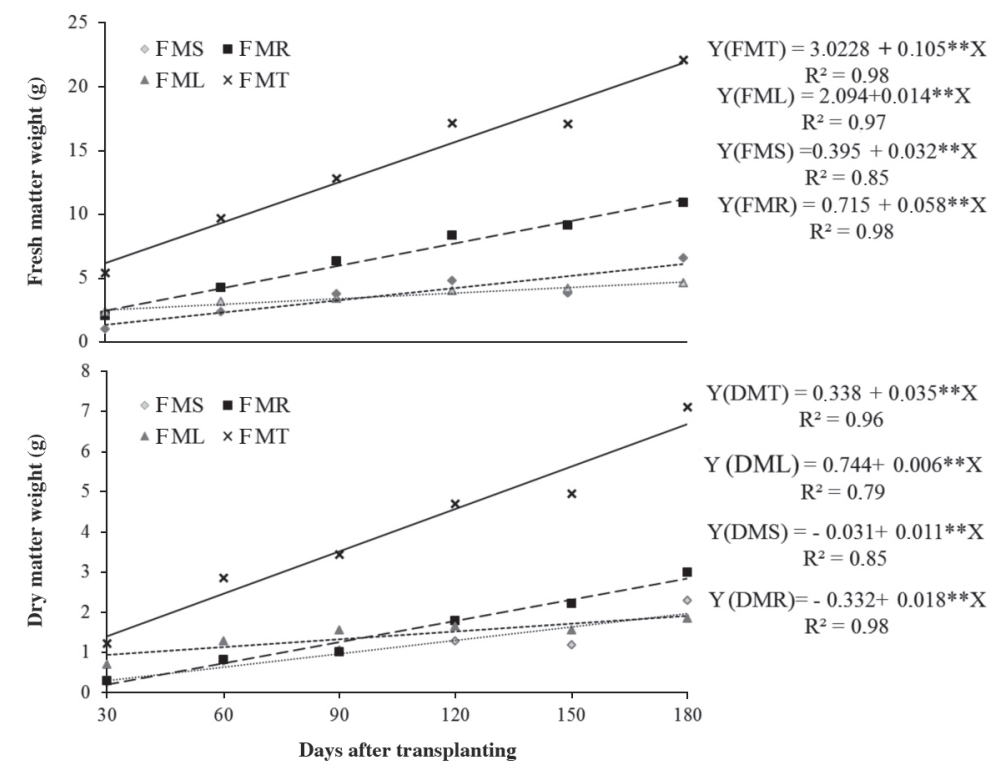

Figure 2. Production of the fresh matter (FM) and dry matter (DM) weights for the total (T), leaves (L), stems (S), and roots (R) in Anacardium othonianum seedlings as a function of days after transplanting. 
et al. (2003) observed an average fortnightly growth rate for soursop seedlings of $1.62 \mathrm{~g}$ at 195 DAT for total dry weight.

The following characteristics for the plants at 180 DAT were established as growth patterns: $16.76 \mathrm{~cm}$ for SL, $8.09 \mathrm{~mm}$ for SD, 11.27 leaves per plant for NL, 329.60 $\mathrm{cm}^{2}$ for LA, $21.92 \mathrm{~g} \mathrm{plant}^{-1}$ for total DM weight, $4.62 \mathrm{~g}$ plant $^{-1}$ for leaf FM weight, $6.16 \mathrm{~g} \mathrm{plant}^{-1}$ for stem FM weight, $11.16 \mathrm{~g} \mathrm{plant}^{-1}$ for leaf FM weight, $6.64 \mathrm{~g} \mathrm{plant}^{-1}$ for total DM weight, $1.82 \mathrm{~g} \mathrm{plant}^{-1}$ for leaf DM weight, $1.95 \mathrm{~g} \mathrm{plant}^{-1}$ for stem DM weight, and $2.91 \mathrm{~g} \mathrm{plant}^{-1}$ for root DM weight.

\section{Accumulation of nutrients}

The accumulation of macronutrients throughout the cycle was significantly altered by the evaluation periods (Figure 3 ). The maximum accumulated amount of $\mathrm{N}$ occurred at 94 DAT in leaves. Beginning in this evaluation period, a decrease in $\mathrm{N}$ accumulation was observed (Figure 3). The total $\mathrm{N}$ accumulation at 180 DAT according to the regression equation was $0.0803 \mathrm{~g} \mathrm{plant}^{-1}$, which was distributed as $0.027 \mathrm{~g}$ in leaves, $0.0173 \mathrm{~g}$ in stems, and $0.036 \mathrm{~g}$ in roots (Figure 3 ), and this distribution suggested that $33.97,21.40$, and $44.63 \%$ of $\mathrm{N}$ contained in the plant was found in leaves, stems, and roots, respectively. At $195 \mathrm{~d}$ of cultivation the $\mathrm{N}$ content in soursop seedlings was $177.35 \mathrm{mg} \mathrm{plant}^{-1}$ (Barbosa et al., 2003). At $120 \mathrm{~d}$ of cultivation in a hydroponic system with 'Paluma' and 'Século XXI' guava seedlings (Psidium guajava L.), Franco et al. (2007) reported N contents of 0.552 and $0.585 \mathrm{~g} \mathrm{plant}^{-1}$, respectively. In 'Pedro Sato' guava seedlings at 120 DAT, Augostinho et al. (2008) reported $\mathrm{N}$ contents of $0.22,0.049$, and $0.065 \mathrm{~g} \mathrm{plant}^{-1}$ in leaves, stems, and roots, respectively.

The largest P content occurred in the roots when the seedlings were at 169 DAT. At the end of the cycle, the amount of accumulated $\mathrm{P}$ was $0.021 \mathrm{~g} \mathrm{plant}^{-1}$ with $0.004 \mathrm{~g}$ in leaves (18.85\% total $\mathrm{P}$ accumulated in the plant), 0.005 $\mathrm{g}$ in stems (23.95\% total $\mathrm{P}$ accumulated in the plant), and $0.012 \mathrm{~g}$ in roots (57.20\% total $\mathrm{P}$ accumulated in the plant) (Figure 3). The amount of $\mathrm{P}$ in soursop seedlings at 195 d cultivation is $8.21 \mathrm{mg}$ plant $^{-1}$ (Barbosa et al., 2003). At 120 d cultivation in a hydroponic system, 'Paluma' and 'Século XXI' guava seedlings have P contents of 0.064 and 0.066 g plant $^{-1}$, respectively (Franco et al., 2007). In 'Pedro Sato' guava seedlings at 120 DAT, the content of $\mathrm{P}$ in leaves, stems, and roots is $0.028,0.006$, and $0.01 \mathrm{~g}$ plant $^{-1}$, respectively (Augostinho et al., 2008).

The greatest amount of accumulated $\mathrm{K}$ at 180 DAT was $0.051 \mathrm{~g} \mathrm{plant}^{-1}$ with $25.46 \%(0.013 \mathrm{~g})$ in leaves, $25.70 \%$ $(0.013 \mathrm{~g})$ in stems, and $48.84 \%(0.025 \mathrm{~g})$ in roots (Figure $3)$. In soursop seedlings at 195 days of cultivation, Barbosa et al. (2003) reported a K content of $327.12 \mathrm{mg} \mathrm{plant}^{-1}$. In 'Paluma' and 'Século XXI' guava seedlings at $120 \mathrm{~d}$ of cultivation in a hydroponic system, the $\mathrm{K}$ contents were 0.726 and $0.696 \mathrm{~g} \mathrm{plant}^{-1}$, respectively (Franco et al.,
2007). In 'Pedro Sato' guava seedlings at 120 DAT, the K contents in leaves, stems, and roots were $0.26,0.064$, and $0.053 \mathrm{~g} \mathrm{plant}^{-1}$, respectively (Augostinho et al., 2008).

The maximum amount of Ca occurred at 180 DAT in roots. At 180 DAT, the plant accumulated $0.087 \mathrm{~g}$, which corresponded to $0.023 \mathrm{~g}$ in leaves, $0.020 \mathrm{~g}$ in stems, and $0.044 \mathrm{~g}$ in roots (Figure 3). In soursop seedlings at 195 d cultivation, the amount of Ca was $159.74 \mathrm{mg} \mathrm{plant}^{-1}$ (Barbosa et al., 2003). At 120 d cultivation in a hydroponic system, Franco et al. (2007) reported Ca contents of 0.293 and $0.302 \mathrm{~g} \mathrm{plant}^{-1}$ 'Paluma' and 'Século XXI' guava seedlings, respectively. At 120 DAT in 'Pedro Sato' guava seedlings, Augostinho et al. (2008) identified Ca contents of $0.10,0.042$, and $0.047 \mathrm{~g} \mathrm{plant}^{-1}$ in leaves, stems, and roots, respectively.

The greatest accumulation of $\mathrm{Mg}$ occurred at 174 DAT in roots. At the end of the seedling crop cycle, the accumulated $\mathrm{Mg}$ value was $0.0112 \mathrm{~g} \mathrm{plant}^{-1}$ with $0.003 \mathrm{~g}$ in leaves, $0.0028 \mathrm{~g}$ in stems, and $0.0054 \mathrm{~g}$ in roots (Figure 3). The Mg content obtained in soursop seedlings at $195 \mathrm{~d}$ cultivation was $22.42 \mathrm{mg}$ plant $^{-1}$ (Barbosa et al., 2003). At $120 \mathrm{~d}$ of cultivation in a hydroponic system, 'Paluma and "Século XXI" guava seedlings have Mg contents of 0.039 and $0.041 \mathrm{~g} \mathrm{plant}^{-1}$, respectively. In 'Pedro Sato' guava seedlings at 120 DAT, Augostinho et al. (2008) reported $\mathrm{Mg}$ contents of $0.02,0.007$, and 0.006 g plant $^{-1}$ in leaves, stems, and roots, respectively.

The maximum amount of accumulated $\mathrm{S}$ occurred at 169 DAT in roots. The accumulation of $\mathrm{S}$ in the plants at 180 DAT was $0.0061 \mathrm{~g} \mathrm{plant}^{-1}$ with $0.0013 \mathrm{~g}$ in leaves, $0.0014 \mathrm{~g}$ in stems, and $0.0034 \mathrm{~g}$ in roots (Figure 3). At 120 d cultivation in a hydroponic system, Franco et al. (2007) reported S contents of 0.073 and 0.066 in 'Paluma' and 'Século XXI' guava seedlings, respectively. At 120 DAT in 'Pedro Sato' guava seedlings, Augostinho et al. (2008) reported S contents of $0.033,0.008$, and $0.006 \mathrm{~g} \mathrm{plant}^{-1}$ in leaves, stems, and roots, respectively.

The total sum of $\mathrm{N}, \mathrm{P}, \mathrm{K}, \mathrm{Ca}, \mathrm{Mg}$, and $\mathrm{S}$ accumulated by the plant at 180 DAT was $0.256 \mathrm{~g}$, and the DM weight was $7.10 \mathrm{~g}$ (Figure 3). Therefore, the accumulation of macronutrients in the plant represented $3.60 \%$ of the DM weight. Augostinho et al. (2008) found 5.3\% total nutrient accumulation in relation to the DM weight for 'Pedro Sato' guava trees, and Silva Júnior et al . (2006) found 17\% total nutrient accumulation in relation to the DM weight for melon trees (Cucumis melo L.) The accumulation of macronutrients in $A$. othonianum seedlings had the following order: $\mathrm{Ca}>\mathrm{N}>\mathrm{K}>\mathrm{P}>\mathrm{Mg}>\mathrm{S}$. For the 'Pedro Sato' guava, the order is as follows: $\mathrm{K}>\mathrm{N}>\mathrm{Ca}>\mathrm{P}>\mathrm{S}>$ Mg (Augostinho et al., 2008).

During the production cycle of seedlings, leaf B accumulation was not influenced at any time in the evaluation periods with an average value of $0.0089 \mathrm{~g}$ plant $^{-1}$ (Figure 4). The greatest accumulation of B occurred at 180 DAT in roots. The accumulated amount of B was $0.024 \mathrm{~g} \mathrm{plant}^{-1}$ with $0.00441 \mathrm{~g}$ in leaves, $0.0096 \mathrm{~g}$ in stems, 

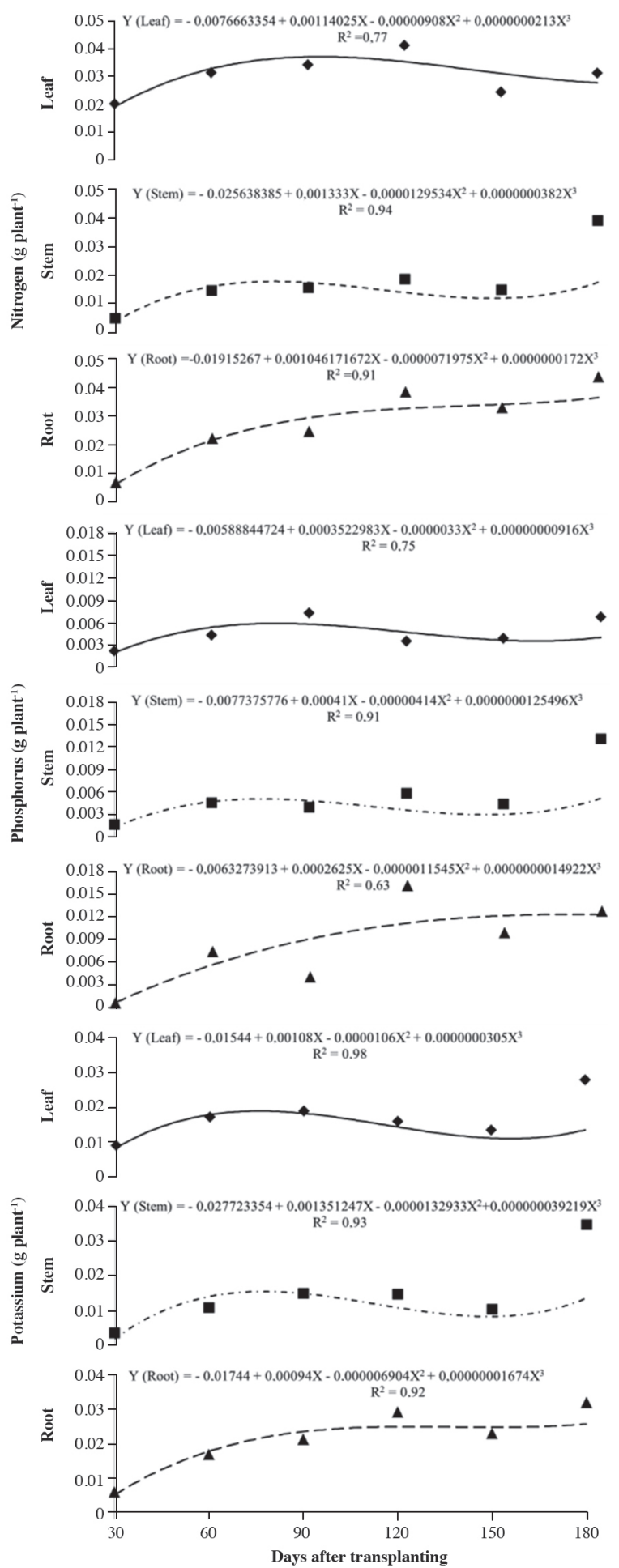
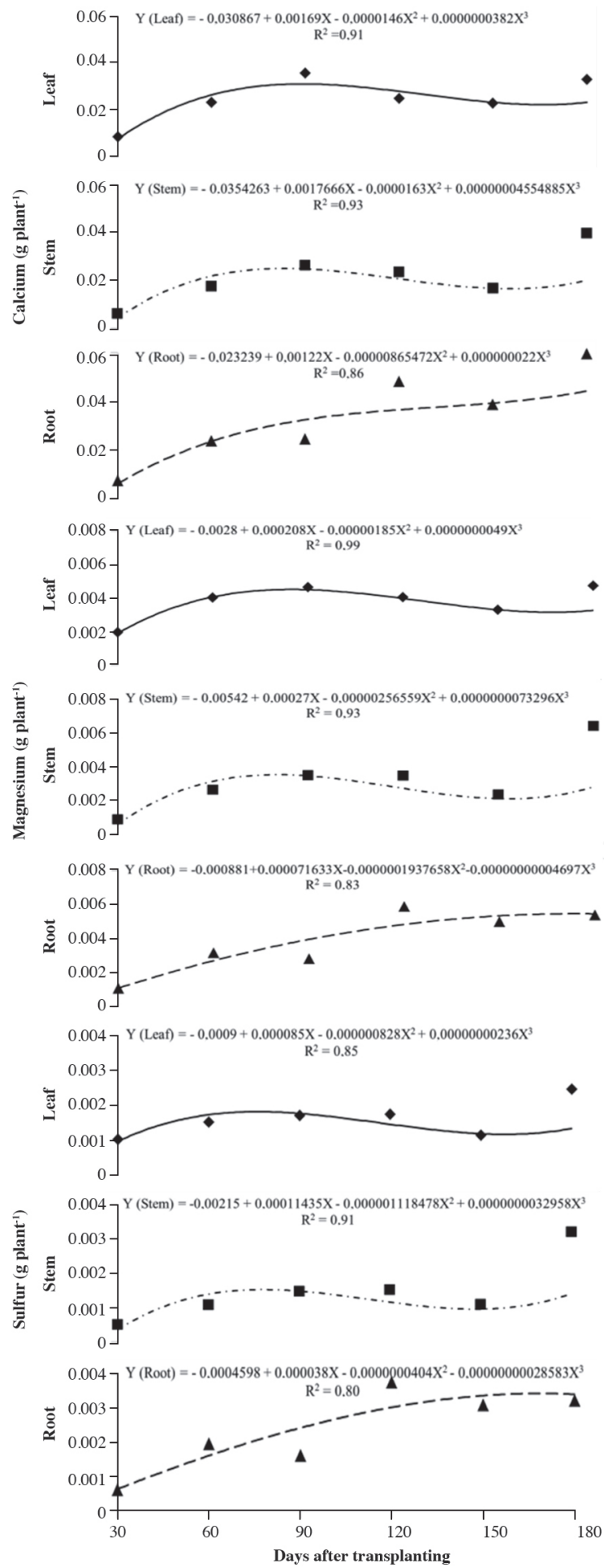

Figure 3. The accumulation of macronutrients (N, Ca, $\mathrm{P}, \mathrm{Mg}, \mathrm{K}$, and $\mathrm{S}$ ) in the leaves, stems, and roots of Anacardium othonianum seedlings as a function of days after transplanting.

and $0.0108 \mathrm{~g}$ in roots (Figure 4). In 'Paluma' and 'Século XXI' guava at 135 DAT, Franco et al. (2008) reported B contents of $0.45,0.13$, and $0.12 \mathrm{~g} \mathrm{plant}^{-1}$ in leaves, stems, and roots, respectively. At 120 DAT in the 'Pedro Sato',
Augostinho et al. (2008) reported B contents of 0.454 and $0.069 \mathrm{~g} \mathrm{plant}^{-1}$ in leaves and stems, respectively.

The accumulated $\mathrm{Cu}$ amount occurred at $180 \mathrm{DAT}$ in roots. At the end of the cycle, the accumulated $\mathrm{Cu}$ content 

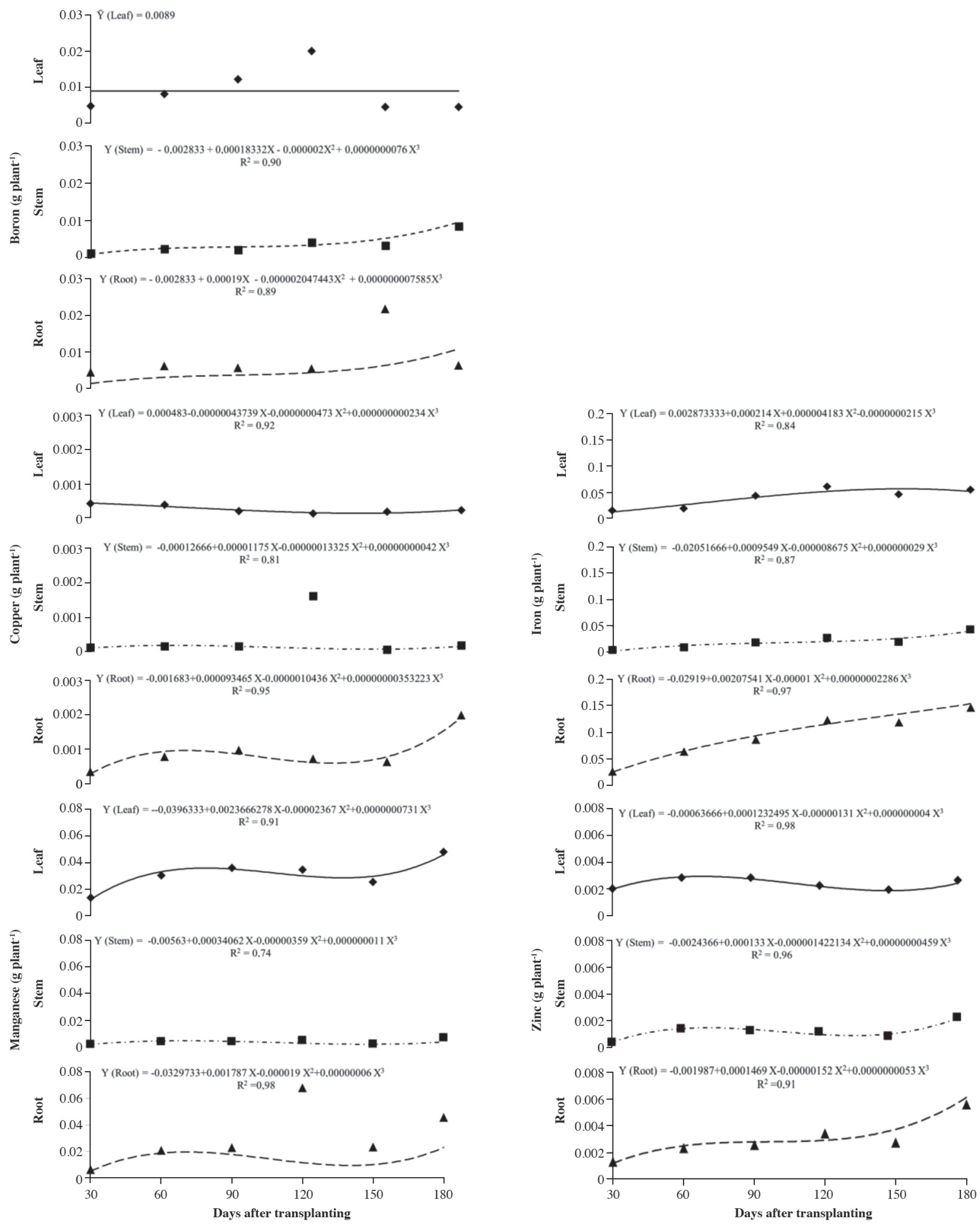

Figure 4. The accumulation of micronutrients $(\mathrm{B}, \mathrm{Fe}, \mathrm{Cu}, \mathrm{Zn}, \mathrm{Mn})$ in leaves, stems, and roots in Anacardium othonianum seedlings as a function of days after transplanting.

was $0.00227 \mathrm{~g} \mathrm{plant}^{-1}$ with $0.0002 \mathrm{~g}$ in leaves, 0.00017 $\mathrm{g}$ in stems, and $0.0019 \mathrm{~g}$ in roots (Figure 4). In soursop seedlings at $195 \mathrm{~d}$ cultivation, Barbosa et al. (2003) reported a $\mathrm{Cu}$ content of $0.068 \mathrm{mg} \mathrm{plant}^{-1}$. At $135 \mathrm{DAT}$ in 'Paluma' and 'Século XXI' seedlings, the $\mathrm{Cu}$ content in leaves, stems, and roots was $0.069,0.041$ and 0.036 g plant ${ }^{-1}$, respectively (Franco et al., 2008). At 120 DAT in the 'Pedro Sato' guava cultivar, $\mathrm{Cu}$ content in leaves 
and stems was 0.02 and $0.0130 \mathrm{~g} \mathrm{plant}^{-1}$, respectively (Augostinho et al., 2008).

The greatest accumulation of Mn occurred at 180 DAT in leaves. The Mn content accumulated by the plant was $0.0715 \mathrm{~g}$ with $0.045 \mathrm{~g}$ in leaves, $0.0035 \mathrm{~g}$ in stems, and $0.023 \mathrm{~g}$ in roots (Figure 4). In soursop seedlings at 195 d cultivation, Barbosa et al. (2003) found a Mn content of $0.23 \mathrm{mg}$ plant ${ }^{-1}$. In 'Paluma' and 'Século XXI' at 135 DAT, the Mn content in leaves, stems, and roots is 1.90 , 0.52 and 0.95 g plant $^{-1}$, respectively (Franco et al., 2008). At 120 DAT in the 'Pedro Sato', Augostinho et al. (2008) reported Mn contents of 1.07 and $0.381 \mathrm{~g} \mathrm{plant}^{-1}$ in leaves and stems, respectively.

The largest amount of Fe occurred at 180 DAT in roots. At the end of the crop cycle of the seedlings, Fe accumulation was $0.2437 \mathrm{~g} \mathrm{plant}^{-1}$, with $0.051 \mathrm{~g}$ in leaves, $0.039 \mathrm{~g}$ in stems, and $0.1537 \mathrm{~g}$ in roots (Figure 4). In soursop seedlings at $195 \mathrm{~d}$ of cultivation, the Fe content is $1.31 \mathrm{mg} \mathrm{plant}^{-1}$ (Barbosa et al., 2003). In 'Paluma' and 'Século XXI' seedlings at 135 DAT, Franco et al. (2008) found $\mathrm{Fe}$ contents of $1.83,0.43$, and $4.55 \mathrm{~g} \mathrm{plant}^{-1}$ in leaves, stems and roots, respectively. In 'Pedro Sato' seedlings at 120 DAT, Fe contents of 0.89 and $0.21 \mathrm{~g}$ plant $^{-1}$ have been found in leaves and stems, respectively (Augostinho et al., 2008).

The $\mathrm{Zn}$ content was greatest at $180 \mathrm{DAT}$ in roots. The amount of accumulated $\mathrm{Zn}$ at 180 DAT was $0.0105 \mathrm{~g}$ plant $^{-1}$ with $0.0024 \mathrm{~g}$ in leaves, $0.0021 \mathrm{~g}$ in stems, and $0.006 \mathrm{~g}$ in roots (Figure 4). In soursop seedlings at 195 d cultivation, Barbosa et al. (2003) found a $\mathrm{Zn}$ content of $0.51 \mathrm{mg} \mathrm{plant}^{-1}$. In 'Paluma' and 'Século XXI' at 135 DAT, the Zn content in leaves, stems, and roots is 0.424 , 0.18 , and $0.26 \mathrm{~g} \mathrm{plant}^{-1}$, respectively (Franco et al., 2008). In 'Pedro Sato' at 120 DAT, Augostinho et al. (2008) found $\mathrm{Zn}$ contents of 0.20 and $0.135 \mathrm{~g} \mathrm{plant}^{-1}$ in leaves and stems, respectively.

The total sum of $\mathrm{B}, \mathrm{Cu}, \mathrm{Mn}, \mathrm{Fe}$, and $\mathrm{Zn}$ accumulated by the plant was $0.35 \mathrm{~g}$, and the DM weight of the plant was $7.10 \mathrm{~g}$ (Figure 4). Therefore, the accumulated micronutrients in the plant represented $4.92 \%$ of total DM weight. The micronutrient accumulation in A. othonianum seedlings had the following order: $\mathrm{Fe}>\mathrm{Mn}>\mathrm{B}>\mathrm{Zn}>$ $\mathrm{Cu}$. Similar results have been found by Augostinho et al. (2008).

According to the results of the present study, the largest accumulation of $\mathrm{N}$ and $\mathrm{Mn}$ occurred in leaves unlike the other nutrients, which had high accumulation amounts in the roots. Nutrient amounts are variable because they depend on soil conditions, climate conditions, nutrient availability, plant morphological characteristics, and plant physiological characteristics (Marschner, 1995).

\section{CONCLUSION}

Plant growth was continuous throughout the cycle with the following maximum values at $180 \mathrm{~d}$ after transplanting:
$16.76 \mathrm{~cm}$ for stem length, $8.09 \mathrm{~mm}$ for stem diameter, 11.27 leaves per plant for number of leaves, and 329.60 $\mathrm{cm}^{2}$ for leaf area. The monthly rates of accumulation of fresh matter and DM weights of the plant were 3.15 and $1.05 \mathrm{~g}$, respectively. The accumulation of nutrients in the Anacardium othonianum seedlings had the following order: $\mathrm{Ca}>\mathrm{N}>\mathrm{K}>\mathrm{P}>\mathrm{Mg}>\mathrm{S}$ for macronutrients and $\mathrm{Fe}>\mathrm{Mn}>\mathrm{B}>\mathrm{Zn}>\mathrm{Cu}$ for micronutrients.

\section{ACKNOWLEDGEMENTS}

The authors would like to thank the Brazilian National Agency for the Support and Evaluation of Graduate Education (Coordenação de Aperfeiçoamento de Pessoal de Nível Superior, CAPES) for the concession of the postdoctorate grant and the Goiás State Research Foundation (Fundação de Amparo à Pesquisa do Estado de Goiás, FAPEG) for the financial support. The authors would also like to thank Mr. Arlindo Thomaz da Silva and family for the donation of the plant material used in this study.

\section{LITERATURE CITED}

Agostini-Costa, T.S., J.P. Faria, R.V. Naves, e R.F. Vieira. 2006. Cajus do Cerrado. p. 136-151. In Vieira, R.F., T. Agostini-Costa, D.B. Silva, F.R. Ferreira, e S.M. Sano (eds.) Frutas nativas da Região Centro-Oeste do Brasil. Embrapa Recursos Genéticos e Biotecnologia, Brasília, Brasil.

Augostinho, L.M.D., R.M. de Prado, D.E. Rozane, e F. Narimâ. 2008. Acúmulo de massa seca e marcha de absorção de nutrientes em mudas de goiabeira 'Pedro Sato'. Bragantia 67:577-585.

Barbosa, Z., I. Soares, e L.A. Crisostomo. 2003. Crescimento e absorção de nutrientes por mudas de gravioleira. Revista Brasileira de Fruticultura 25:519-522.

Barros, L.M. 2002. Caju: produção aspectos técnicos. Frutas do Brasil 30. 148 p. Embrapa Agroindústria Tropical, Brasília, Brasil.

Correa, G.C., R.V. Naves, M.R. Rocha, L.J. Chaves, e J.D. Borges. 2008. Determinações físicas em frutos e sementes de baru (Dipteryx alta Vog.), cajuzinho (Anacardium othonianum Rizz.) e pequi (Caryocar brasiliense Camb.), visando melhoramento genético. Bioscience Journal 24(4):42-47.

Franco, C.F., R.M. Prado, L.F. Braghirolli, e D.E. Rozane. 2007. Curva de crescimento e marcha de absorção de macronutrientes em mudas de goiabeira. Revista Brasileira de Ciência do Solo 31:1429-1437.

Franco, C.F., R.M. Prado, L.F. Braghirolli, e D.E. Rozane. 2008. Marcha de absorção dos micronutrientes para mudas de goiabeiras cultivares Paluma e Século XXI. Bragantia 67:83-90.

Gurgel, M.T., C.A. Uyeda, H.R. Gheyi, F.H.T. de Oliveira, P.D. Fernandes, e F.V. da Silva. 2010. Crescimento de meloeiro sob estresse salino e doses de potássio. Revista Brasileira de Engenharia Agrícola e Ambiental 14:3-10.

Hoagland, D., and D.I. Arnon. 1950. The water culture method for growing plants without soil. California Agriculture Experimental Station Circular 347. College of Agriculture, University of California, Davis, California, USA.

Hunt, R., D.R. Causton, B. Shipley, and P. Askew. 2002. A modern tool for classical plant growth analysis. Annals of Botany 90:485488.

Jandel Scientific. 1991. User's manual. 280 p. Jandel Corporation, San Rafael, California, USA.

Malavolta, E., G.C. Vitti, e A.S. Oliveira. 1997. Avaliação do estado nutricional das plantas: princípios e aplicações. 319 p. Associação Brasileira para Pesquisa da Potassa e do Fosfato, Piracicaba, Brasil. 
Marschner, H. 1995. Mineral nutrition of higher plants. 889 p. Academic Press, New York, USA.

Silva Júnior, M., J.F. Medeiros, F.H.T. Oliveira, e I. Dutra. 2006. Acúmulo de matéria seca e absorção de nutrientes pelo meloeiro "pele-de-sapo". Revista Brasileira Engenharia Agrícola e Ambiental 10:364-368.
Sousa, V.D. de, e E.F. Coelho. 2001. Manejo de fertirrigação em fruteiras. Cap. 2. p. 289-317. In Folegatti, M.V. (ed.) Fertirrigação: flores, frutas e hortaliças. Agropecuária, Guaíba, Rio Grande do Sul, Brasil.

Taiz, L., and E. Zeiger. 2004. Nutrição mineral. p. 95-113. In Taiz, L., e E. Zeiger (eds.) Fisiologia vegetal. $3^{\mathrm{a}}$ ed. Artmed, Santana, Porto Alegre, Brasil. 